\title{
Cytokine Storm and Mucus Hypersecretion in COVID-19: Review of Mechanisms
}

This article was published in the following Dove Press journal:

Journal of Inflammation Research

\author{
Mohsin Ali Khan' \\ Zaw Ali Khan' \\ Mark Charles ${ }^{2}$ \\ Pushpendra Pratap ${ }^{2}$ \\ Abdul Naeem (1D ${ }^{2}$ \\ Zainab Siddiqui $\mathbb{D}^{3}$ \\ Nigar $\mathrm{Naqvi}^{4}$ \\ Shikha Srivastava ${ }^{4}$ \\ 'Reseach \& Development Department, \\ Era's Lucknow Medical College \& \\ Hospital, Lucknow, Uttar Pradesh, India; \\ ${ }^{2}$ Metabolic Research Unit, Era's Lucknow \\ Medical College \& Hospital, Lucknow, \\ Uttar Pradesh, India; ${ }^{3}$ Department of \\ Pathology, Era's Lucknow Medical College \\ \& Hospital, Lucknow, Uttar Pradesh, \\ India; ${ }^{4}$ Department of Nutrition, Era's \\ Lucknow Medical College \& Hospital, \\ Lucknow, Uttar Pradesh, India
}

Correspondence: Zaw Ali Khan

Era's Lucknow Medical College \& Hospital

Era University, Hardoi Road, Lucknow,

Uttar Pradesh 22600I, India

Tel +9l 9839445514

Email zawali@erauniversity.in

\begin{abstract}
Mucus is an integral part of the respiratory physiology. It protects the respiratory tract by acting as a physical barrier against inhaled particles and microbes. Excessive inflammation in conditions such as COVID-19 can result in over-production of mucus which obstructs the airway. Build-up of mucus can also contribute to recurrent airway infection, causing further obstruction. This article summarizes the current understanding and knowledge of respiratory mucus production and proposes the role of cytokine storm in inducing sudden mucus hypersecretion in COVID-19. Based on these cascades, the active constituents that inhibit or activate several potential targets are outlined for further research. These may be explored for the discovery and design of drugs to combat cytokine storm and its ensuing complications.
\end{abstract}

Keywords: COVID-19, cytokine storm, mucus, coronavirus, viral infection

\section{Introduction}

Nasal blockage or respiratory congestion is among the most common symptoms experienced in primary care as well as tertiary care. It can be particularly severe and even lethal in COVID-19 due to the formation of mucus plugs. Transmission of COVID-19 appears to occur primarily through dispersal of droplets generated from the respiratory tract when an infected person talks, coughs, or sneezes. Large amounts of the SARS-CoV-2 virus have been reported in sputum and nasal specimens, which account for the transmission through respiratory droplets. Numerous studies conclude that the recent coronavirus infection causes an allergic reaction in respiratory tract mucosa, which activates mucin secretion and modulates its chemical structure to enable the virus to enter the cells. ${ }^{1-3}$ Thereafter, SARS-CoV-2 initiates neutrophil and mucus-mediated inflammatory pathways. ${ }^{4}$

SARS-CoV-2 is shed predominantly in upper and lower airway tract secretions. ${ }^{5-9}$ Patients with severe COVID-19 infections are likely to develop acute respiratory distress syndrome (ARDS), consisting of hypoxemic respiratory failure associated with neutrophilia, mucus deposition in bronchi, and bronchiectasis. ${ }^{10}$ Therefore, better understanding is needed of the mechanisms underlying secretions, and how to control them. The increase in mucus production and secretion is likely due to mucus cell metaplasia since pulmonary inflammatory diseases are often associated with excessive mucus secretion. Computerized tomography (CT) images of COVID-19 depict the incidence of mucoid impaction in lungs. Studies of CT imaging in the pulmonary parenchymal region of COVID-19 patients have reported a $64 \%$ occurence of pathological fluid in the alveolar sacs which appears multifocal, patchy, or segmented and is distributed around sub-pleural 
areas or along broncho-vascular bundles. ${ }^{11,12,13}$ Increase in sputum volume and mucus hypersecretion associated symptoms have been seen in up to $40 \%$ of patients. The mucus in these patients is also found to be more viscous than that in those with chronic obstructive pulmonary disease (COPD). Lastly, the formation of colloidal mucus plugs is more frequent in these patients.

The role of inflammatory stimuli in influencing mucus cell levels remains uncertain. Here we review recently published work which defines events in the immune system and downstream epithelial cascade related to continuous metaplasia of mucus cells.

\section{Physiology of Airway Mucus Secretion}

In the pulmonary system, mucus is a component of the epithelial lining fluid (ELF) or airway surface liquid
(ASL). The major part of the respiratory tract is covered by it. The ASL comprises a sol layer and an overlying gel layer which are known as the perciliary liquid layer (PCL) and the mucus layer, respectively (see Figure 1).

Mucus consists primarily of water ( $\sim 95 \%)$. The major nonaqueous component is mucin, while proteoglycans, lipids, proteins, and DNA are also present in smaller quantities. ${ }^{15}$ Mucin is secreted by goblet cells which are columnar epithelial cells present in the respiratory, gastrointestinal and reproductive tracts. Mucin-containing secretory vesicles are present at the upper surface of goblet cells. Short microvilli projections are present on the upper surface of goblet cells which give an increased surface area for secretion. ${ }^{16,17}$

Mucin, the main protein component of mucus, functions primarily as a barrier, and consists of MUC5AC and MUC5B as important secreted mucin genes. Their sizes range from $200 \mathrm{kDa}$ to $200 \mathrm{MDa}$. Chains of carbohydrates make up

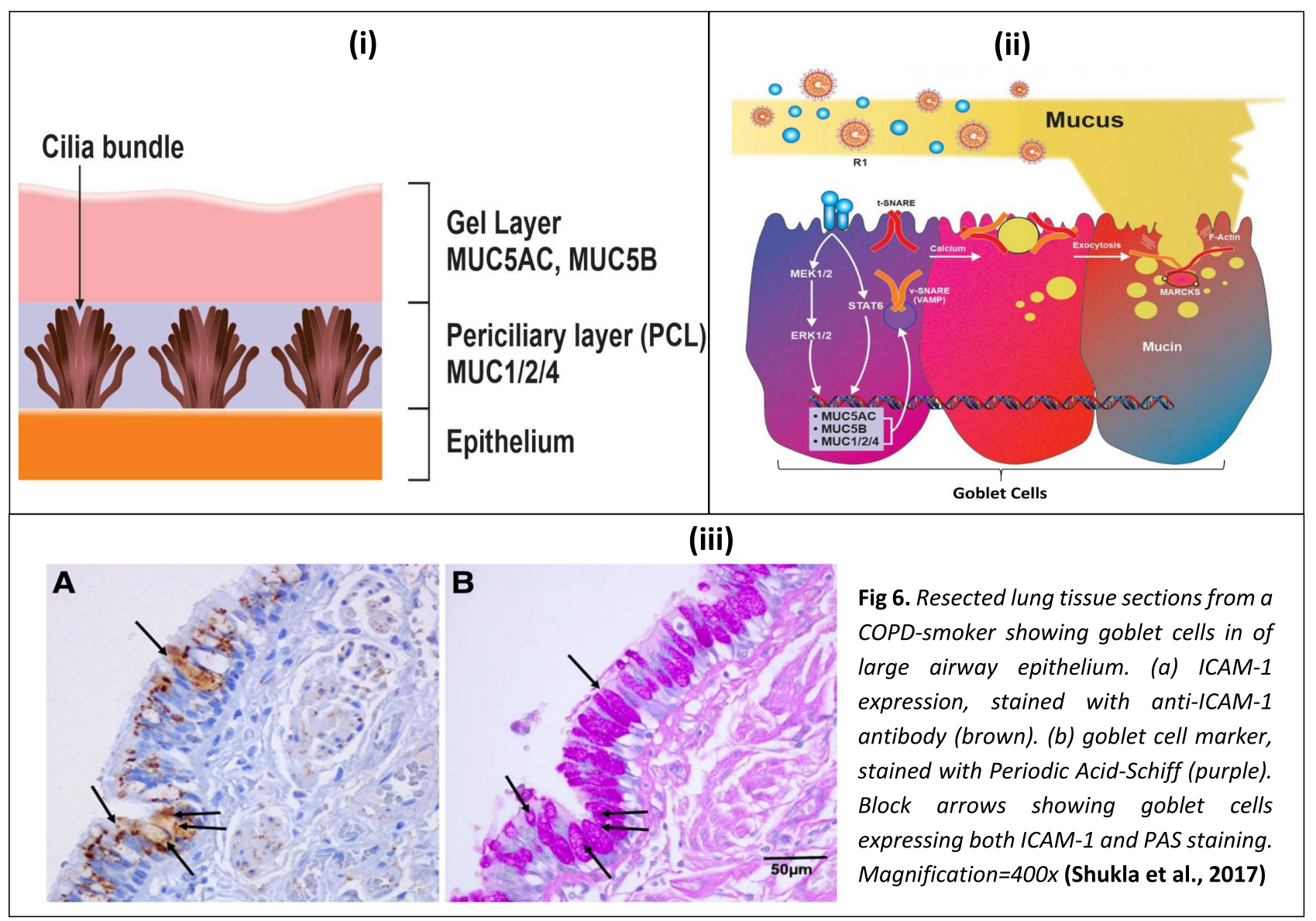

Figure I Schematic illustration of a goblet cell, associated signalling for mucous secretion and microscopic images of goblet cells: (i) The gel on brush model describes mucus existing in two discrete layers, a more viscous gel layer on top and a periciliary layer (PCL) below. The gel layer contains the secreted mucins MUC5AC and MUC5B whilst the PCL contains the membrane-tethered mucins MUCI, MUC2 \& MUC4; (ii) Viral infection induced signalling involved in mucus secretion; (iii) Lung tissue sections from a COPD-smoker showing goblet cells of large airway epithelium.

Notes: Figure I (iii) reproduced with permission from Shukla SD, Mahmood MQ, Weston S, et al. The main rhinovirus respiratory tract adhesion site (ICAM-I) is upregulated in smokers and patients with chronic airflow limitation (CAL). Respir Res. 2017;18(I):6. ${ }^{14}$ 
around $80 \%$ of the weight of mucins. ${ }^{18}$ Since mucin is quite large, it is packaged in secretory vesicles in a dehydrated state. $^{8}$ The release of mucin is governed by fusion proteins such as SNARE (N-ethyl-maleimide-sensitive factor attachment protein receptor) and MARCKS (Myristoylated Alanine-Rich C Kinase Substrate). The secretion occurs in the presence of high $\mathrm{pH}$ and low calcium concentration. ${ }^{19-22}$

Past studies have shown that cytokines IL4, IL5, IL9, and IL13 upregulate mucus gene expression and mucus cell hypersecretion. ${ }^{23,24}$ Apart from cytokines, various other stimuli such as smoking generate reactive oxygen species. These stimuli upregulate numerous downstream cascades, which trigger multiple signaling pathways via mitogenactivated protein kinase and other signaling cascades. These signaling cascades induce goblet cell differentiation in the airway, causing excessive synthesis and secretion of mucin. ${ }^{25,26}$ Such rampant hypersecretion leads to clinical conditions such as chronic obstructive pulmonary disease, asthma, bronchiectasis, and other respiratory disease conditions such as those observed in COVID-19 patients.

\section{Association Between Viral Infection and Mucus Production}

The inflammatory response that occurs after viral infection is similar to that observed in asthma and other respiratory conditions in which the role of mucus is profound. Viruses such as influenza, negative-strand RNA viruses such as respiratory syncytial virus (RSV) and rhinoviruses (RV) and lung colonization by pathogenic opportunistic bacteria have shown enhanced exacerbation in bronchial epithelial cells. $^{27,28}$ For example, RSV infection in the upper respiratory tract is distinguished by inflammation and obstruction in the airways tract due to the formation of mucus plugs containing mucus, fibrin protein, cellular debris, and lymphocytes. Generally, these viruses activate the downstream signaling cascades of inflammatory markers through chemokines, as shown in Figure 1C. These in turn trigger multiple signaling pathways that result in goblet cell differentiation and hyperplasia in the airway, leading to the synthesis of MUC proteins, particularly MUC5AC, MUC5B, MUC1, MUC2, and MUC4 followed by their secretion. ${ }^{29}$ Studies have shown that RSV and human metapneumovirus (hMPV) stimulate varying production of mucin in A549 cell line. ${ }^{30}$ Despite similarities in the structure and pathogenicity of these two viruses, they cause different expressions of MUC2, MUC5AC, and MUC5B as well as membrane- bound mucins. $^{31}$ Thus, certain viral infections may uniquely alter the composition of mucus in respiratory epithelium.

\section{Mucus Hypersecretion in COVID-19}

Formation of mucus plugs has been observed in COVID 19 patients, causing airway obstruction and respiratory failure in a significant proportion of such patients. Severe mucoid tracheitis is detected in 33\% of COVID-19 autopsies. $^{32}$

\section{Association of Immune Response with Mucus Secretion}

Sungnank et al. have stated that the nasal epithelial serves as the point of infection of SARS-CoV-2, from where it moves to the lower respiratory tract. ${ }^{33}$ The respiratory mucosa functions as a defensive layer against pathogens. The layer has the ability to trap an invading pathogen through sticky secretions and then move it out via ciliary action. $^{34}$ Arumugham et al. suggest that SARS-CoV-2 overstimulates the mucosa in a pathophysiology similar to other viruses such as dengue virus. This leads to the activation of an inflammatory cascade and the release of various inflammatory cytokines and chemokines. ${ }^{35}$ This is in line with other studies that show SARS-CoV-2 activates the inflammatory response and induces increased secretion of respiratory mucosa. ${ }^{36}$

In an experiment by Cohn et al., the role of IL-4 and IL-5 in mucus production and cell recruitment mediated by TH2 cells is well described. Activation of CD4 T cells by IL-4 causes the differentiation of th0 cells to th2 cells which in turn activates IL-4 secretion, maintaining a positive feedback loop. ${ }^{37}$ Interleukin 4 induces the transcription of MUC5AC by activation of the JAK3/STAT 6 pathway. STAT 6 is involved in the activation of CLCA1 (calcium activated chloride channel 1) which activates MAPK signaling ultimately resulting in mucin production. Th2 cells help in recruitment of lymphocytes and eosinophils into lungs causing the over-secretion of MUC5AC in the airway resulting in goblet cell hyperplasia and damage of the ciliary layer of epithelial cells. ${ }^{38}$ Very-LateActivation-Antigen-4 (VLA-4) is present on eosinophils and $\mathrm{T}$ lymphocytes which has the ability to bind with Vascular Cell Adhesion Molecule 1 (VCAM-1) and allows selective entry of eosinophils into injured tissues. ${ }^{38}$

In various studies it has been found that defects in gene expression and function of Cystic Fibrosis Transmembrane Conductance Regulator (CFTR) is associated with airway mucus hypersecretion. CFTR acts as a cAMP-dependent 
chloride channel. ${ }^{39}$ In an experiment performed on murine cell lines, tissue expression pattern of CLCA1 intersecting with that of CFTR confirms the fact that both genes participate in the pathogenesis of cystic fibrosis. The channel transports chloride ions, controlling the movement of water in tissues, which is necessary for the production of mucus. ${ }^{40}$ Mutation in the CFTR gene disrupts the movement of water and chloride ions out of the cell causing the mucus to be thick and sticky. Trapped chloride ions in cells cannot attract the fluids necessary to hydrate the cell surface and in the absence of the fluids, mucus becomes dehydrated and takes on a viscous consistency. ${ }^{41}$ CFTR modulator therapy proposed by Jarosz-Griffiths and coworkers could confer additional benefit to patients and may also contribute to improved clinical outcomes. ${ }^{42}$

\section{Role of Inflammation in Airway Mucus Hypersecretion}

The symptoms in COVID-19 and elevated levels of inflammatory markers in patients indicate that a severe cytokine storm develops in this disease. Recent studies support that inflammation causes mucus hypersecretion. Studies have shown that most cases infected with SARS-CoV-2 have normal WBC counts or in some cases lymphocytopenia. Patients showing severe conditions have significant increases in neutrophil levels. Their blood urea and D-dimer levels are also significantly high, whereas there is a reduction in their lymphocyte count. ${ }^{43}$ The levels of several pro-inflammatory cytokines such as IL6, IL10, and TNF- $\alpha$ are elevated. Moreover, the blood report of patients admitted to intensive care units (ICUs) have shown increases in IL-2, IL-7, and IL-10. ${ }^{44-46}$ The inflammatory response can induce mucus hypersecretion which can obstruct the respiratory tract, limiting airflow and thereby aggravating the already declining lung function. ${ }^{47}$

Furthermore, the pro-inflammatory cascades alter the composition of mucus and compromise its clearance by cilia. ${ }^{48}$ This leads to recurrent infection in airway tracts, causing more obstruction in the respiratory tract, thereby creating a vicious cycle. COVID-19 patients have higher levels of several proinflammatory markers, namely IL-1 $\beta$, IL-6, IL-2, IL-13, and TNF $\alpha$ as shown in Figure 2 along with their crosstalk. ${ }^{49}$

The crosstalk of these cytokines and their downstream signaling upregulates several other inflammatory cytokines. IL-2, IL-4, and IL-6 upregulate the levels of IL-4, IL-5, IL-6, and IL-13 via STAT5, STAT6, and NFAT, respectively. IL-5 also upregulates levels of IL-6, IL-1, and TNF $\alpha$ via STAT1.
TNF $\alpha$ through NF- $\kappa B$ activation leads to upregulation of IL1 beta and IL-8. Apart from cytokines, histamine released from mast cell degranulation during inflammatory response results in EGF and adenosine synthesis via ERk1/2 upregulation, as shown in Figure 2. The inflammation caused by these cytokines can result in mucus hypersecretion which corresponds to the complication arising in COVID-19 patients. The subsequent section describes these mechanisms of inflammatory cytokines in mucus hypersecretion.

\section{Overexpression of Mucin Through STAT Mediated Signaling}

The JAK-STAT signaling pathway is a series of interactions between proteins in the cytoplasm. It is involved in various processes leading to STAT dimerization and activation of transcription genes in the DNA. IL-4 via its receptor activates STAT6, leading to self-upregulation and activation of the MUC5AC gene complex consisting of $\mathrm{MUC1} / 2 / 4{ }^{50}$ Meanwhile IL-8 via its receptor leads to SOCS1 protein (Suppressor of cytokine signaling) upregulation leading to IL-4 mRNA synthesis via STAT1. IL-4 mRNA also induces $\mathrm{Ca}(2+)$-activated $\mathrm{Cl}(-)$ channel (CLCA1). Binding of CLCA1 to its receptor (CLCA1$\mathrm{R}$ ), leads to the inhibition of FOXA2 (Forehead Box A2) which has a down regulatory effect on MUC5AC gene, through MAPK via SAM Pointed Domain Containing ETS Transcription Factor (SPDEF) protein. ${ }^{51}$ The same signaling pathway is used by interleukin 13 and IL-18 that are modulated by IL-6, ${ }^{52-56}$ as shown in Figure 3

IL-9 can induce pleiotropic function in various immune cells as well as normal cells. ${ }^{57}$ IL-9 signal transduction requires the receptors which have a common $\gamma$ chain. ${ }^{58} \mathrm{IL}-$ 9R receptor activates JAK1 and JAK3, which through downstream signal transduction leads to the activation of STAT1, STAT3, and STAT5. Dimerization of these STATs enhances the mucus hypersecretion. ${ }^{59}$ IL-2 via its receptor IL-2R causes the activation of Janus kinases family proteins, followed by recruitment to phosphorylated STAT5, which dimerize and attach to the nucleus and initiate IL-5 mRNA transcription. Therefore IL-2 causes the upregulation of IL-5 via the JAK/STAT pathway. ${ }^{60,61}$

\section{Overexpression of Mucin Through MAPK Mediated Signaling}

The MAPK mediated signaling (known as Ras-Raf-MEKERK pathway) consists of a chain protein molecule that transduces signal from a receptor induced by pro-inflammatory 


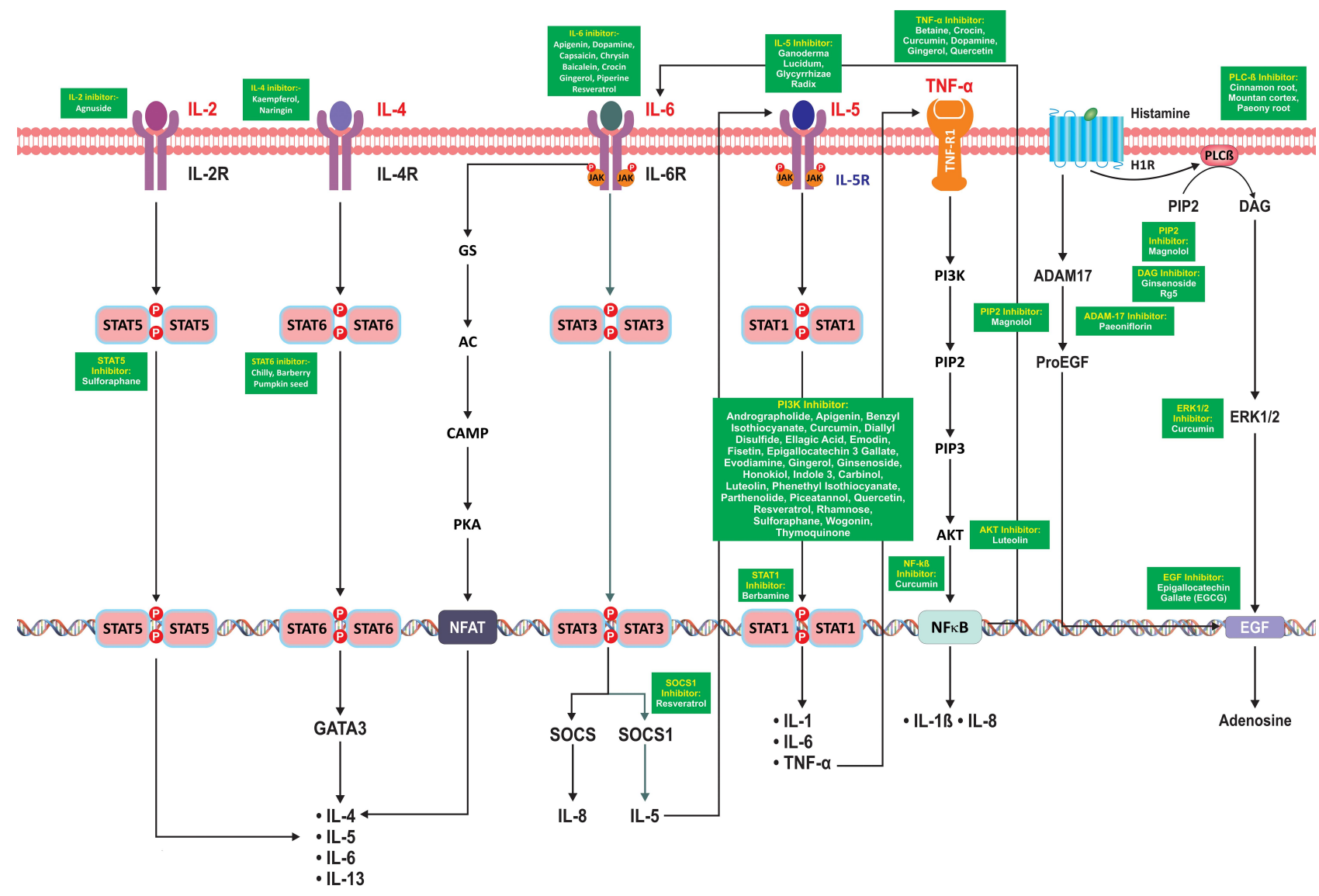

Figure 2 Crosstalk of interleukins, IL-4, IL-2, IL-6, IL-5, TNF- $\alpha$, histamine and the downstream signaling pathways leading to the production of interleukins involved in mucus hypersecretion. Note: The cytokines written in red are elevated in COVID-19 patients.

cytokines from the cell surface to the DNA present in the nucleus. Elevated levels of IL-6 found in COVID-19 would contribute to pathogenesis by promoting mucus hypersecretion. Studies have demonstrated that IL-6 is an important cytokine for the development of mucus metaplasia in the airways in response to inhaled allergens. ${ }^{62}$ As shown in Figure 4, IL-6 binds to its receptor IL-6R and activates Growth factor receptor-bound protein 2 and Son of Sevenless complex (GRB2/SOS) which further leads to the activation of Ras and Raf signaling cascades. These cascades activate JNK via the p38/MAPK pathway. Activated JNK upregulates MUC5AC gene in the airway epithelium which enhances the mucus hypersecretion followed by exocytosis of mucin via MARCKS \& SNARE. ${ }^{63,64}$

The expression of IL-5 is upregulated by IL-2, an interleukin which is elevated in severely affected COVID-19 patients. Mucus production due to IL-5 was initially observed in a pulmonary transgenic mouse model. The mechanism consists of IL-5 binding to IL-5R and activating GRB2/SOS which leads to activation of mucus genes (MUC5AC, MUC5B, and MUC1/2/4) in the airway epithelium, which enhances mucin synthesis and hypersecretion via MARCKS and SNARE. ${ }^{65,66}$

IL-17, a proinflammatory cytokine secreted by $\mathrm{T}$ cells, is elevated by IL-6. IL-17 has been found to be upregulated in the mice model of asthma which be inhibited by anti-IL-17 antibody which cause reduction in granulocyte influx. ${ }^{67,68}$ Mucin expression is induced by IL-17 in cell cultures of airway epithelial cells via upregulation of the MUC5AC gene through IL-5 and IL-6 mediated signaling.

IL-1 $\beta$ acts as an early response pleiotropic cytokine that is produced by different cells in the pulmonary inflammatory cascade, which is elevated in severely affected COVID-19 patients. Upon binding to its receptor IL1R it causes the activation of MyD88 which leads to the activation of MAPK via MAP3K and MAP2K. ${ }^{69,70}$ IL-1 $\beta$ has been recently shown to increase the expression of MUC5AC gene and mucin secretion in bronchial epithelial cell line. ${ }^{71}$ 


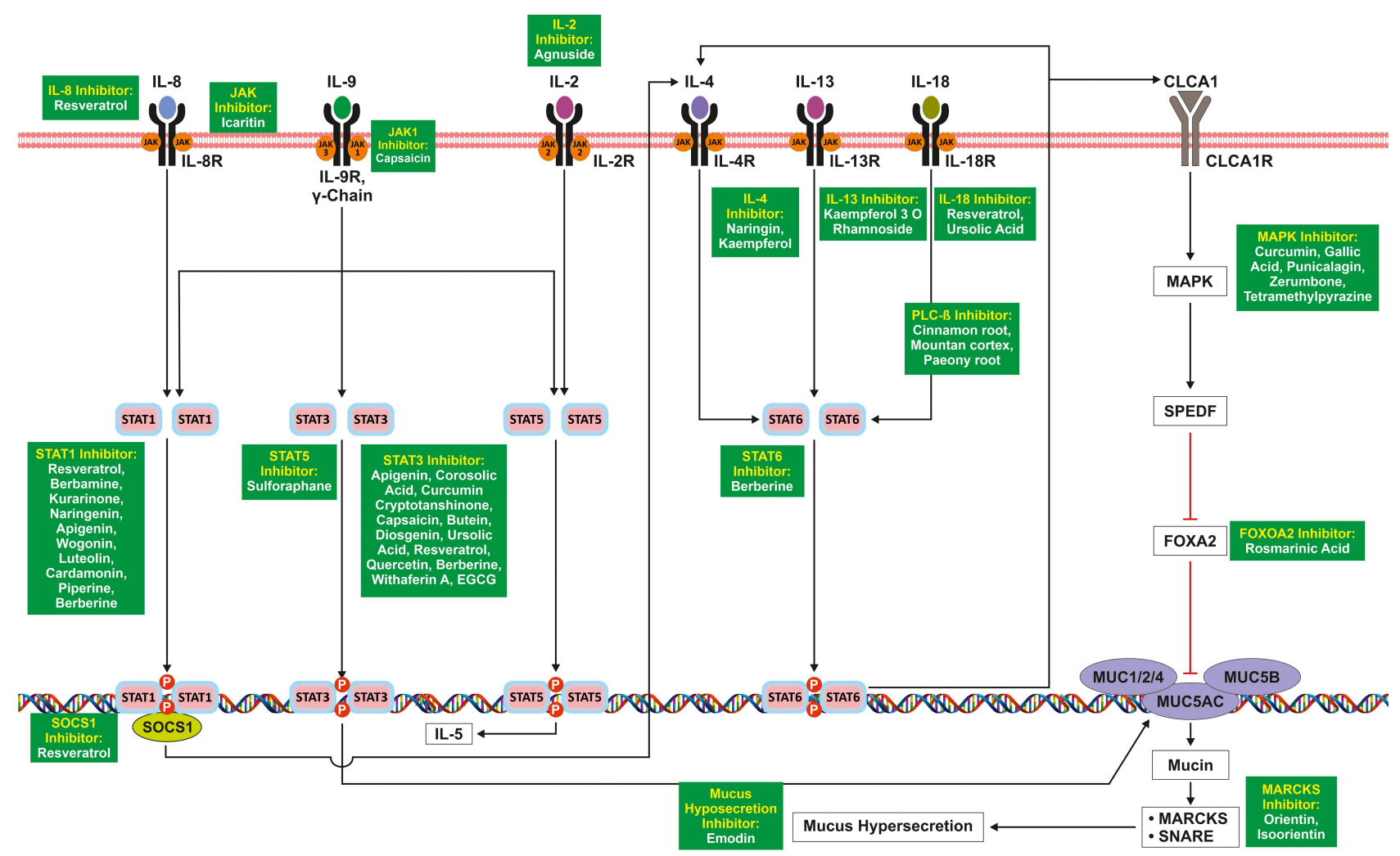

Figure 3 STAT mediated signaling induced by cytokines leading to mucus hypersecretion.

\section{Overexpression of Mucin Through NF-kB Mediated Signaling}

NF-kB (Nuclear factor kappa-light-chain-enhancer of activated $\mathrm{B}$ cells) comprises a group of protein complexes that controls the transcription of DNA, cytokine production namely Il-6, TNF $\alpha$, IL-8, and IL-1 Beta and cell survival. $\mathrm{TNF} \alpha$ is one of the most extensively studied pleiotropic cytokines of the TNF family which is also induced by IL5. ${ }^{72} \mathrm{TNF} \alpha$ has an important role in the innate immune response against invading pathogens before triggering the adaptive immune system. ${ }^{73}$ It acts on the ubiquitously expressed TNFR1. ${ }^{74}$ This receptor ligand interaction causes downstream signaling, leading to phosphorylation of I $\mathrm{I} B$ kinase (IKK) composed of subunits IKK $\alpha$, IKK $\beta$, and thus nuclear factor kappa beta (NF-kB) activation. NF-kB forms a heterodimer composed of $\mathrm{p} 50$ and $\mathrm{p} 65$ proteins ${ }^{73,75}$ This heterodimer interacts with the DNA to increase transcription of pro-inflammatory cytokine genes, such as IL-1B, IL-6, IL8, and TNF $\alpha$ itself, as shown in Figure 5. All of these cause pulmonary inflammation and are known to cause mucus hypersecretion. It also induces MUC5AC overexpression through p38-mitogen activated protein kinases/ERK (MAPK/ERK) and Sp1 in human airway epithelial cells. ${ }^{75}$
TNF- $\alpha$ increases the expression of EGFR in the airways. EGF binds to its receptor (EGFR) and increases the expression of the MUC5AC gene via ERK signaling. EGFR also cause activation of Ras, Raf, and MUC2 via Erk1/2 which enhances the mucus hypersecretion. ${ }^{76}$ The role of ATP in MUC5AC release was examined by stimulating cells with polyinosine-polycytidylic acid. ${ }^{77}$ They found that the concentration of extracellular ATP increased in the NCI-H292 cells due to dsRNA stimulation and viral infection. Binding of adenosine triphosphate (ATP) to P2Y2 receptors causes activation of IP3 and DAG via PIP2 and releases calcium from endoplasmic reticulum which enhances the expression of MUC5AC gene in the airway epithelium. Adenosine via its receptor adenosine $A_{1}$ receptor (Ad1R) through PLC beta also causes activation of the same signaling cascade leading to mucin production.

\section{Leukotriene-Mediated Mucus Over-Secretion}

Leukotrienes are from a class of inflammatory mediators that are produced in leukocytes by the oxidation of arachidonic acid (AA) and other essential fatty acids. Studies using exogenous viruses such as rhinovirus (RV) have 


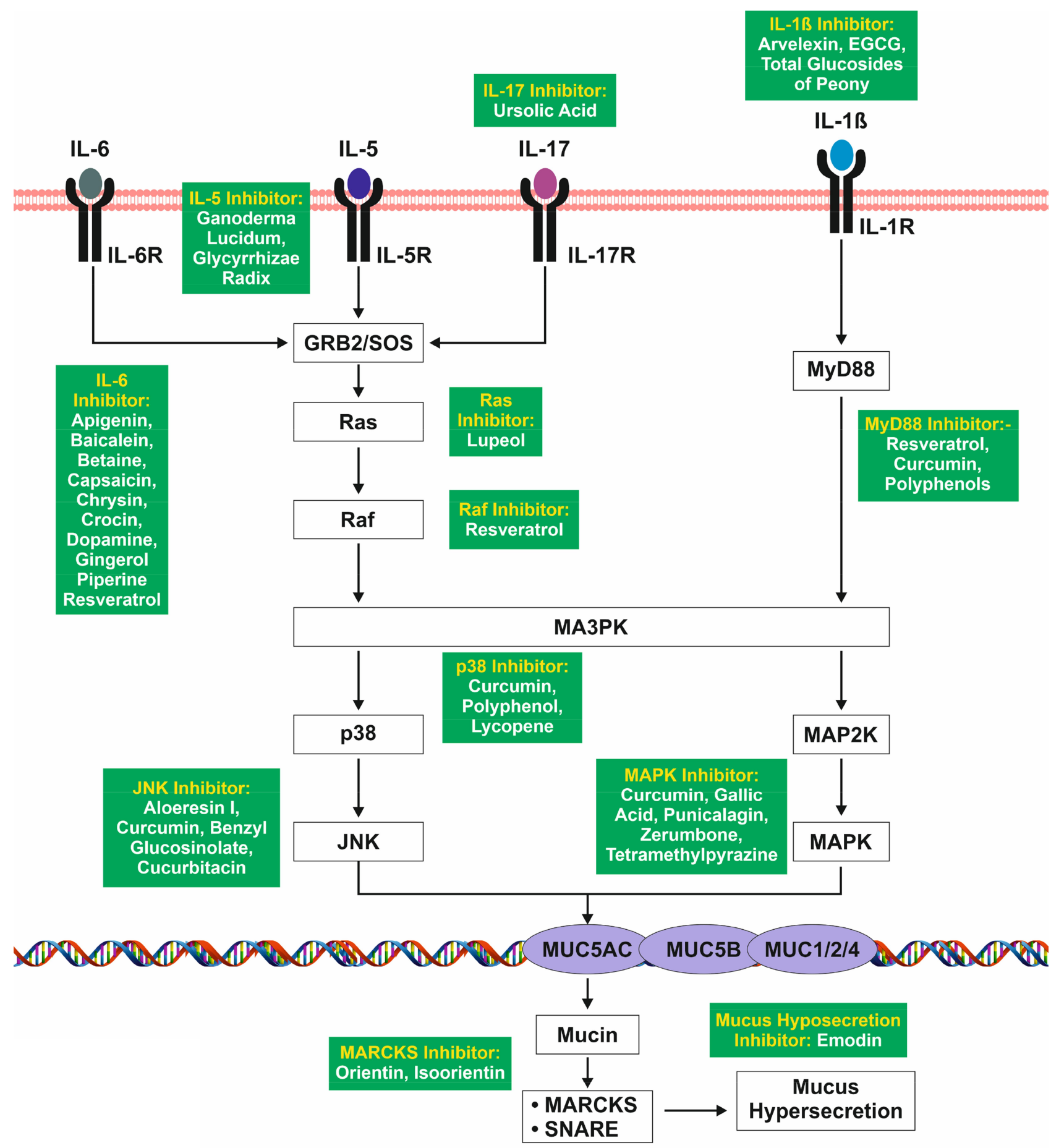

Figure 4 MAPK mediated signaling pathway induced by interleukins leading to mucus hypersecretion.

found CD4-activated efflux of cytokines like IL-5, IL-4, and IL-2, as shown in Figure 6, which leads to B cell proliferation and IgE mediated leukotriene synthesis. ${ }^{78}$

Activation of FceRI via IgE activates the synthesis and release of arachidonic acid (AA).$^{79}$ AA metabolises into hydroperoxyeicosatetraenoic acid (HPETE) and forms leukotriene (LT) A4 by enzyme 5-lipoxygenase. LTC4 synthase converts LTA4 into LTC4, which further converts into LTF4 and LTD4 with the help of carboxypeptidase A and gamma glutamyl transpeptidase. Both LTF4 and LTD4 are converted by gamma glutamyl transpeptidase and dipeptidase separately into LTE $4 .{ }^{80}$ LTE4 provokes mucus 


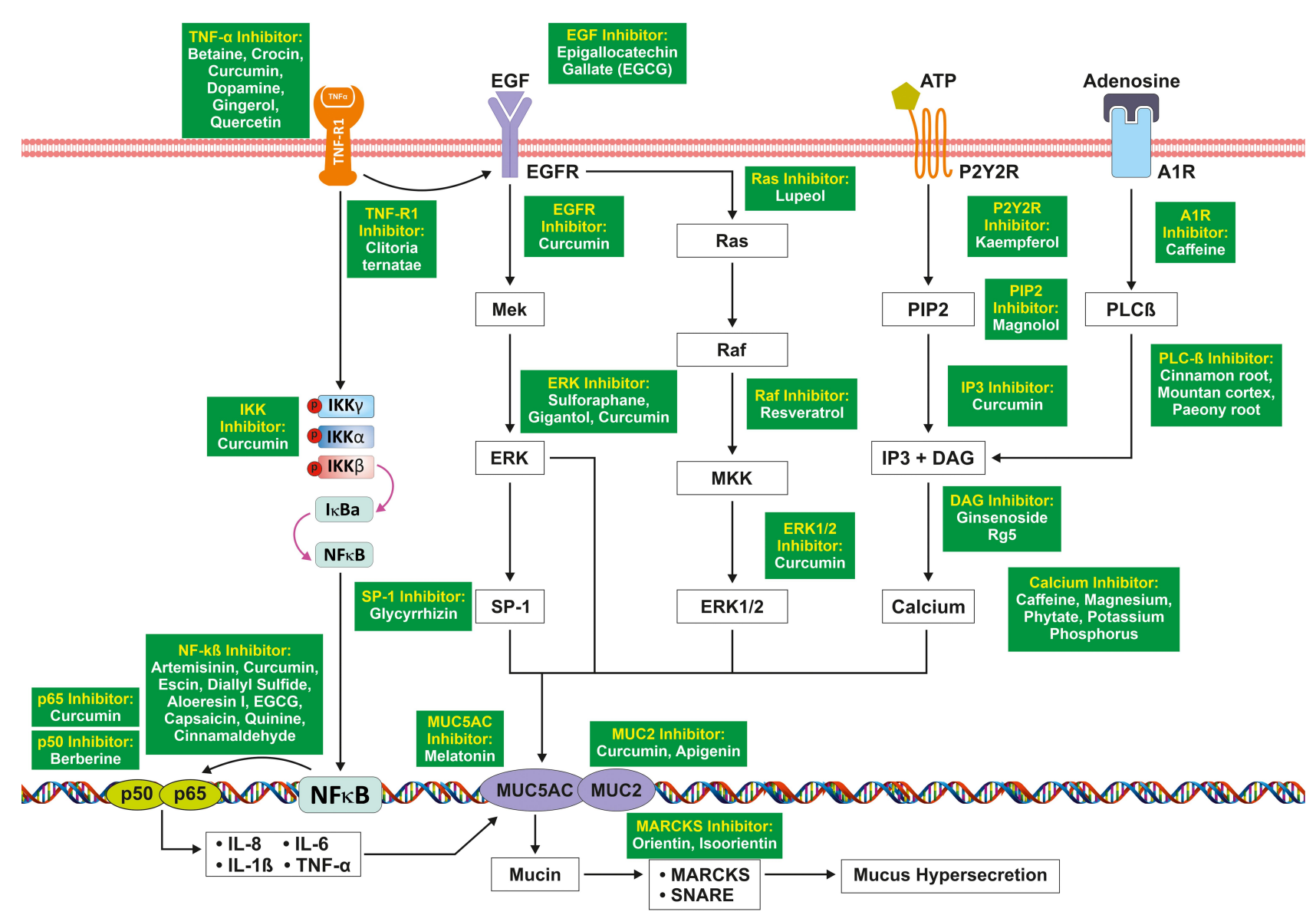

Figure 5 NF-Kß mediated signaling pathway leading to mucus hypersecretion.

hypersecretion via binding with its receptor, Cysteinyl Leukotriene Receptor 1 (CysLT1) ${ }^{81}$ IL-2 is confirmed to be elevated in severe SARS-CoV-2 infection as well. It is also likely that IL-4 and IL-5 would be elevated since they are downstream in the signaling cascade of TNF $\alpha$. Thus, viral induced leukotriene synthesis and a corresponding increase in mucus secretion is likely to be present in COVID-19.

\section{Protective Role of Cytokines}

Considering the severity of inflammation and its importance in COVID-19 patients, it is crucial to identify factors that contribute in the inflammatory response. These include anti-inflammatory cytokines and antibodies, some of which are currently used to treat other inflammatory conditions in the respiratory tract.

\section{Anti-Inflammatory Role of IL-37}

Multiple studies have reported significant anti-inflammatory properties of IL-37 and its mode of action in recent years. ${ }^{86,87}$ These studies demonstrated that IL-37 is capable of inhibiting pro-inflammatory effects that are mediated through activation of receptors belonging to the interleukin-1 receptor/toll-like receptor (TIR) superfamily such as TIRs 2 and 4 and the IL-1 receptor. $^{86}$

IL-37 has shown to modulate inflammation by downregulating response of $\mathrm{Th}_{1}, \mathrm{Th}_{2}$, and $\mathrm{Th}_{17}$ cells. ${ }^{88}$ Studies have demonstrated that locally administering IL-37 can reduce eosinophil levels in bronchoalveolar (BAL) fluid and respiratory tract tissues. Upon binding to IL-18R, IL37 suppresses the expression of IL1 $\alpha$, IL6, IL1 $\beta$, TNF $\alpha$, GCSF, and GMCSF via JAK/STAT pathway. ${ }^{89,90}$ IL-37 inhibits NF- $\mathrm{kB}$ activation of S100A9 via STAT3 and p62.

\section{Anti-Inflammatory Role of IL-27}

IL-27 is a heterodimeric cytokine. IL-27 is primarily secreted by activated macrophages and dendritic cells. ${ }^{91-93}$ Binding of IL-27 to its receptor Il-27R and gp130 leads to activation of STAT1 and inhibits GATA-3 which further downregulates IL-4 and reduces mucin production via MUC5AC. 


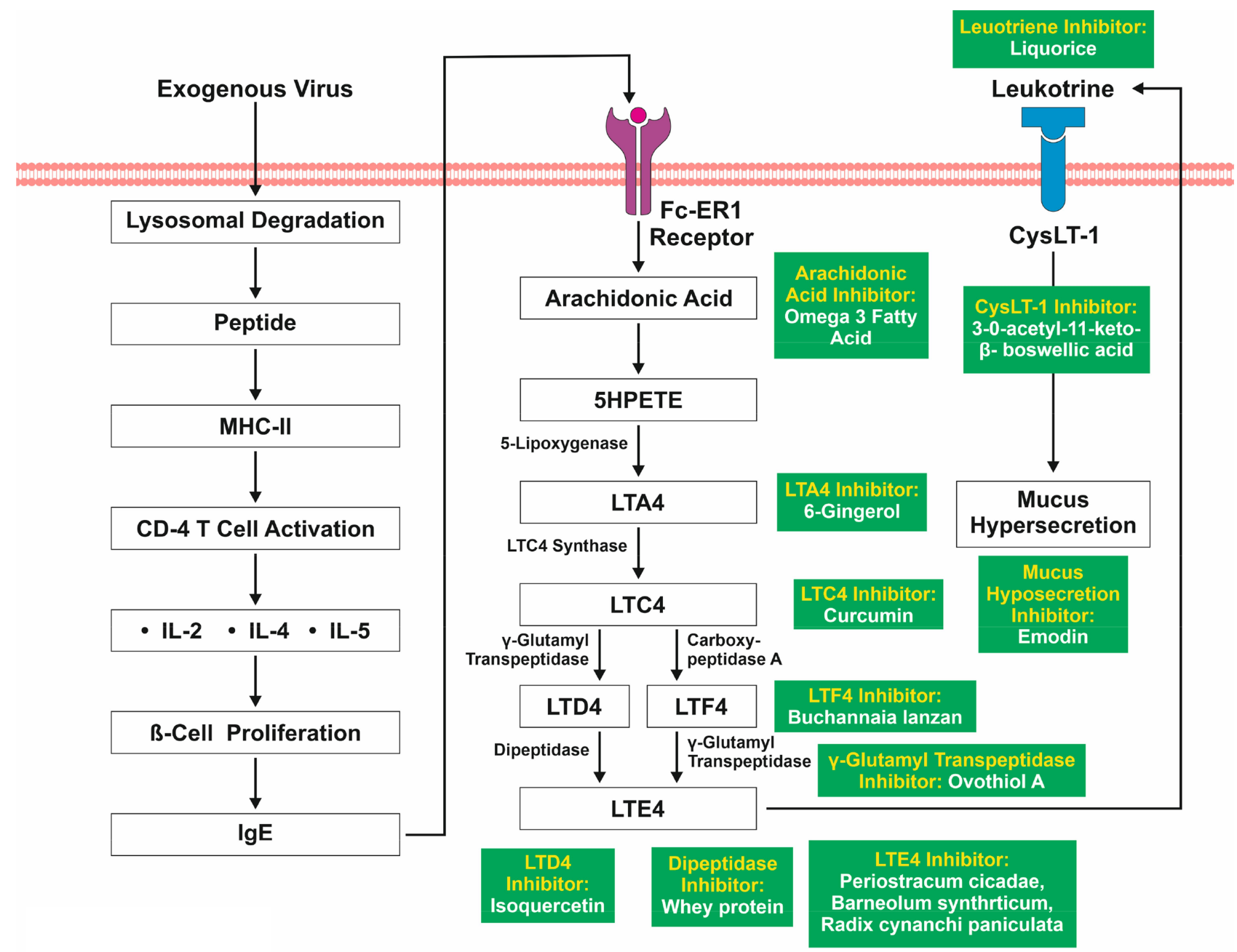

Figure 6 Activation of Viral Induced Leukotriene Initiated Mucus Secretion.

\section{Anti-Inflammatory Role of IL-35}

Interleukin-35 acts as an anti-inflammatory cytokine which is secreted by $\mathrm{T}$ cells and $\mathrm{B}$ cells. ${ }^{94}$ Studied have found that IL-35 induces proliferation of regulatory T cells, inhibiting CD4+ effector cells, and suppressing the development of $\mathrm{Th}_{17}$ cells. ${ }^{95}$ Upon binding to IL-12R $\beta 2 / \mathrm{gp} 130$, IL-35 activates the JAK/STAT pathway to inhibits GATA3, thereby regulating the expression of MUC5AC..$^{96}$

\section{Anti-Inflammatory Role of IL-38}

IL-38 belongs to the interleukin-1 family. ${ }^{97}$ IL 38 plays a significant role in inflammation and immune responses, acting against pathogenic microorganisms. IL-38 has a binding affinity to IL-1R and IL-36R and inhibits the MAPK mediated downstream signaling, leading to the decreased activation of cytokines through AP1 thereby modulating inflammation, as shown in Figure $7 .^{98-102}$
As shown in various in vitro studies and in animal models for chronic inflammatory diseases, inhibition of specific inflammatory pathways results in diminished production of pro-inflammatory cytokines such as IL- $1 \alpha$, IL$1 \beta$, IL-6, IL-17. In addition to neutralization of single proinflammatory cytokines, the use of anti-IL6 and anti-IL1 drugs may lead to better control of cytokine storms in COVID-19 patients.

\section{Discussion}

Inflammation in the mucosa is the main pathophysiological mechanism leading to congestion in several respiratory tract diseases. It is particularly heightened in COVID-19 due to elevated pro-inflammatory cytokines. The build-up of mucus can also contribute to other complications found in COVID-19 such as venous engorgement, elevation in nasal secretions, and pulmonary edema. Thus, regulation 


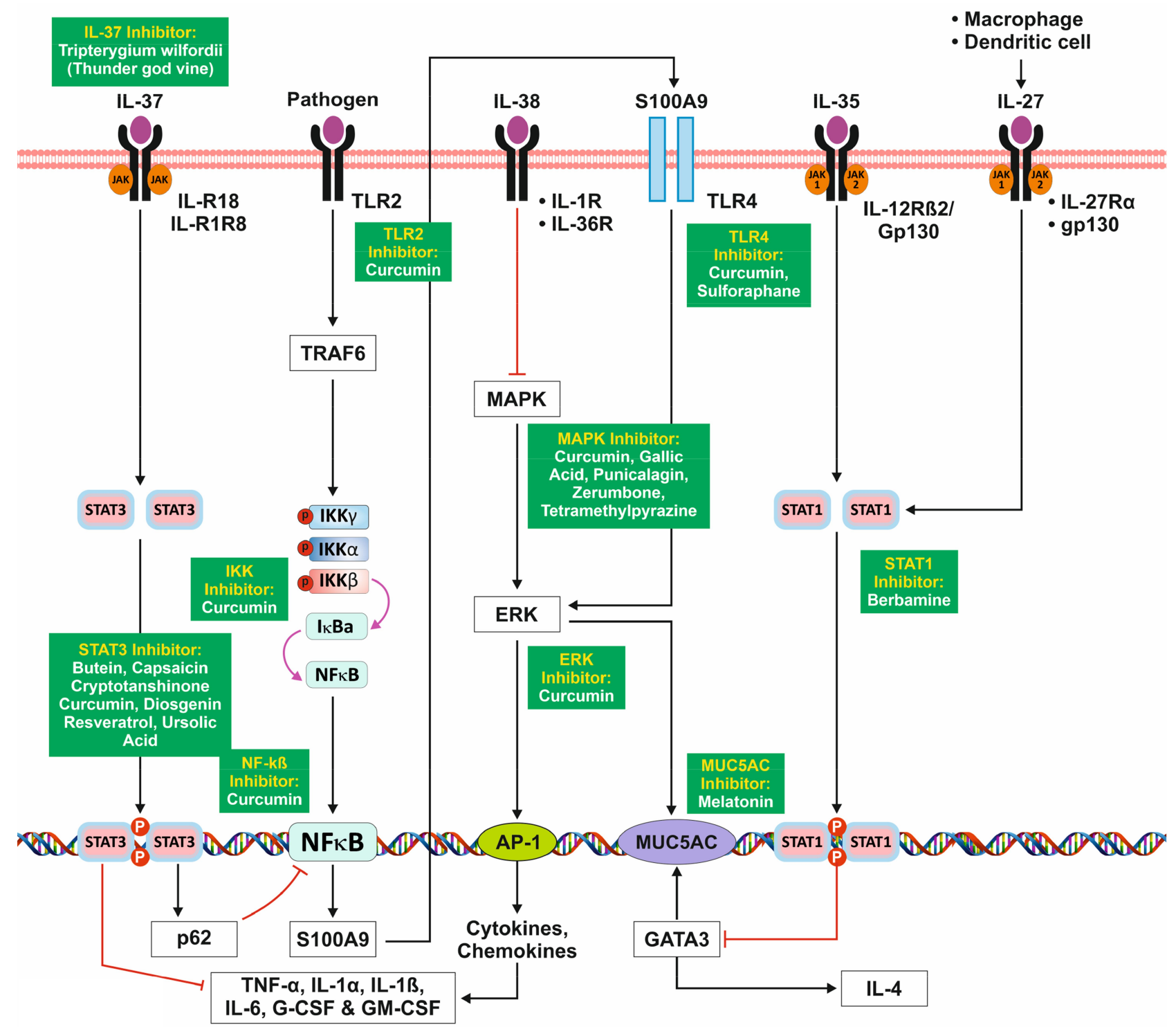

Figure 7 Signaling Pathways of Anti-Inflammatory Cytokines.

of these inflammatory cascades might be crucial in the treatment of severely ill COVID-19 patients.

\section{Anti-Interleukin Drugs}

The use of drugs that inhibit key inflammatory signaling molecules (viz. IL-1 $\beta$, IL-6, TNF $\alpha$ ) may be used. Th2 cytokines, such as IL-5, have been the main therapeutic targets for eosinophilic inflammation-associated pulmonary disease. For the treatment of asthma, the Food and Drug Administration (FDA) approved the use of mepolizumab, an anti IL-5 drug candidate, in $2015 .{ }^{82}$ Since then, reslizumab and benralizumab are two more anti-IL-5 drugs that have also been given FDA approval for use in asthma. ${ }^{83-85}$ Sarilumab, siltuximab and tocilizumab are inhibitors of IL-
6 that are approved by the FDA for use in diseases such as Castleman disease, rheumatologic disorders and cytokine release syndrome. ${ }^{103}$ Anakinra is an IL-1 inhibitor that the FDA approved for use in rheumatoid arthritis and cryopyrinassociated periodic syndromes. ${ }^{104}$ Several clinical trials are underway for the use of these inhibitors in COVID-19. A pilot multicentre study found encouraging results with tocilizumab given to patients with severe COVID-19. ${ }^{105}$ Current drugs and their trials are shown in Table 1.

\section{Anti-Inflammatory Cytokines}

The use of anti-inflammatory cytokines such as IL-27, IL35 , IL-37 and IL-38 can also be explored as a novel 
Table I Potential Therapeutic Drugs and Their Targets Currently Under Trial Against COVID-19

\begin{tabular}{|c|c|c|c|c|c|c|}
\hline S. No. & Drug & Target & Action & Disease & $\begin{array}{l}\text { Ongoing } \\
\text { Clinical Trial }\end{array}$ & References \\
\hline I & Niclosamide & MUC5AC & Inhibitor & Tapeworm infection & $\begin{array}{l}\text { COVID-19 } \\
\text { (Phase 2) }\end{array}$ & 111,112 \\
\hline 2 & Tofacitinib & JAK & Inhibitor & Rheumatoid arthritis & $\begin{array}{l}\text { COVID-19 } \\
\text { (Phase 2) }\end{array}$ & 113,114 \\
\hline 3 & Infliximab & $\begin{array}{l}\text { TNF- } \\
\text { alpha }\end{array}$ & Inhibitor & Rheumatoid arthritis, Ankylosing spondylitis & $\begin{array}{l}\text { COVID-19 } \\
\text { (Phase 2) }\end{array}$ & 115,116 \\
\hline 4 & Tocilizumab & IL-6 & Inhibitor & Cytokine Release Syndrome (CRS) & $\begin{array}{l}\text { COVID-19 } \\
\text { (Phase 3) }\end{array}$ & 117,118 \\
\hline 5 & Secukinumab & IL-17 & Inhibitor & Psoriasis & $\begin{array}{l}\text { COVID-19 } \\
\text { (Phase 2) }\end{array}$ & 119,120 \\
\hline 6 & Canakinumab & IL-I beta & Inhibitor & $\begin{array}{l}\text { Muckle-Wells syndrome and TNF receptor associated } \\
\text { periodic syndrome }\end{array}$ & $\begin{array}{l}\text { COVID-19 } \\
\text { (Phase 3) }\end{array}$ & 121,122 \\
\hline
\end{tabular}

treatment modality. At present, there is no data available for the safety and efficacy of such cytokine therapy. ${ }^{105,106}$

\section{Anti-Inflammatory Active Constituents}

Lastly, regular intake of anti-inflammatory food products may be helpful in mitigating the cytokine storm. Many everyday food products have anti-inflammatory active constituents whose properties have been studied extensively. Ginger, turmeric, and green tea have active constituents that inhibit IL-1 $\beta$, IL-6, TNF $\alpha$, and $\mathrm{NF}-\kappa \mathrm{B} \cdot{ }^{107-110}$

In Figures $2-7$, several anti-inflammatory active constituents are mentioned in green boxes at the site of their reported action. These active constituents along with the natural sources are listed in Supplementary Table S1 that contain active constituents which are known to inhibit various inflammatory cascades that arise due to the cytokine storm. The effect of incorporating such antiinflammatory food substances in the diet of COVID-19 patients can be studied without the risk of any undesired effects. Developing such a modality seems particularly crucial in the absence of specific therapies for targeting cytokine storms in COVID-19.

\section{Conclusion}

Since mucus is a fundamental mechanism for defense against allergens and pathogens, its production increases in the respiratory tract in nearly every instance of airway inflammation. The cytokine storm in COVID-19 is particularly potent for the build-up of mucus due to the onset of several inflammatory cascades associated with mucus production. It is therefore important to understand these cascades for identification of new therapeutic targets and drug discovery. In the meantime, dietary supplementation of COVID-19 patients with foods that are known to inhibit key inflammatory molecules may provide some degree of relief in the mucus production and other symptoms of airway inflammation.

\section{Acknowledgments}

The authors are grateful to Dr Shadab Raza and Dr Mohd. Faheem Khan for their advice in selection of journal for publication. We are also thankful to Dr. M.M.A. Faridi for the encouragement provided by him for the analytical approach of this review. Lastly, we thank the entire management of Era's Lucknow Medical College \& Hospital for supporting this work.

\section{Disclosure}

The authors report no conflicts of interest in this work.

\section{References}

1. Tian S, Hu W, Niu L, Liu H, Xu H, Xiao SY. Pulmonary pathology of early Phase 2019 novel coronavirus (COVID-19) pneumonia in two patients with lung cancer. $J$ Thorac Oncol. 2020;15:700-704. doi:10.1016/j.jtho.2020.02.010

2. Bernheim A, Mei X, Huang M. Chest $\mathrm{CT}$ findings in coronavirus disease-19 (COVID-19): relationship to duration of infection. Radiology. 2020;295. 
3. Khashkhosha HK, Elhadi M. A hypothesis on the role of the human immune system in covid-19 published online ahead of print, [2020 Jul 1]. Med Hypotheses. 2020;143:110066. doi:10.1016/j.mehy.2020.110066

4. Earhart AP, Holliday ZM, Hofmann HV, Schrum AG. Consideration of dornase alfa for the treatment of severe COVID-19 acute respiratory distress syndrome. New Microbes New Infect. 2020;35:100689. doi:10.1016/j.nmni.2020.100689

5. Zhu N, Zhang D, Wang W, et al. A novel coronavirus from patients with pneumonia in China, 2019. $N$ Engl $J$ Med. 2020;382(8):727-733. doi:10.1056/NEJMoa2001017

6. Costela-Ruiz VJ, Illescas-Montes R, Puerta-Puerta JM, Ruiz C, Melguizo-Rodríguez L. SARS-CoV-2 infection: the role of cytokines in COVID-19 disease. Cytokine Growth Factor Rev. 2020;54:62-75. doi:10.1016/j.cytogfr.2020.06.001

7. Jiang Y, Xu J, Zhou C, et al. Characterization of cytokine/chemokine profiles of severe acute respiratory syndrome. Am J Respir Crit Care Med. 2005;171(8):850-857. doi:10.1164/ rccm.200407-857OC

8. Upadhyay J, Tiwari N, Ansari MN. Role of inflammatory markers in corona virus disease (COVID-19) patients: a review. Exp Biol Med. 2020;245(15):1368-1375. doi:10.1177/1535370220939477

9. Ye Z, Zhang Y, Wang Y, et al. Chest CT manifestations of new coronavirus disease 2019 (COVID-19): a pictorial review. Eur Radiol. 2020;1-9.

10. Li X, Ma X. Acute respiratory failure in COVID-19: is it "typical" ARDS? Crit Care. 2020;24(1):198. doi:10.1186/s13054-02002911-9

11. Holtzman MJ, Battaile JT, Patel AC. Immunogenetic programs for viral induction of mucous cell metaplasia. Am J Respir Cell Mol Biol. 2006;35(1):29-39. doi:10.1165/rcmb.2006-0092SF

12. Vetrugno L, Baciarello $\mathrm{M}$, Bignami $\mathrm{E}$, et al. The "pandemic" increase in lung ultrasound use in response to Covid-19: can we complement computed tomography findings? A narrative review. Ultrasound J. 2020;12:39. doi:10.1186/s13089-020-00185-4

13. Lai SK, Wang YY, Wirtz D, Hanes J. Micro- and macrorheology of mucus. Adv Drug Deliv Rev. 2009;61(2):86-100. doi:10.1016/j. addr.2008.09.012

14. Shukla SD, Mahmood MQ, Weston Set al. The main rhinovirus respiratory tract adhesion site (ICAM-1) is upregulated in smokers and patients with chronic airflow limitation (CAL). Respir Res2017;18(1):6 doi:10.1186/s12931-016-0483-8

15. Ohar JA, Donohue JF, Spangenthal S. The role of guaifenesin in the management of chronic mucus hypersecretion associated with stable chronic bronchitis: a comprehensive review. Chronic Obstr Pulm Dis. 2019;6(4):341-349.

16. Hodges RR, Dartt DA. Conjunctival goblet cells. Encyclopedia Eye. 2010;369-376.

17. Knoop KA, Newberry RD. Goblet cells: multifaceted players in immunity at mucosal surfaces. Mucosal Immunol. 2018;11:1551-1557. doi:10.1038/s41385-018-0039-y

18. Zanin M, Baviskar P, Webster R, Webby R. The interaction between respiratory pathogens and mucus. Cell Host Microbe. 2016;19(2):159-168. doi:10.1016/j.chom.2016.01.001

19. Adler KB, Tuvim MJ, Dickey BF. Regulated mucin secretion from airway epithelial cells. Front Endocrinol. 2013;4:129. doi:10.3389/fendo.2013.00129

20. Chen $\mathrm{C}$, Thai P, Yoneda $\mathrm{K}$, et al. A peptide that inhibits the function of Myristoylated Alanine-Rich C Kinase Substrate (MARCKS) reduces lung cancer metastasis. Oncogene. 2014;33:3696-3706. doi:10.1038/onc.2013.336

21. Wickström C, Davies JR, Eriksen GV, et al. MUC5B is a major gel-forming, oligomeric mucin from human salivary gland, respiratory tract and endocervix: identification of glycoforms and C-terminal cleavage. Biochem J. 1998;15(334):685-693. doi:10.1042/bj3340685
22. Hovenberg HW, Davies JR. Carlstedt.Different mucins are produced by the surface epithelium and the submucosa in human trachea: identification of MUC5AC as a major mucin from the goblet cells. I Biochem J. 1996;15(318):319-324. doi:10.1042/ bj3180319

23. Dabbagh K, Takeyama K, Lee HM, et al. IL-4 induces mucin gene expression and goblet cell metaplasia in vitro and in vivo. J Immunol. 1999;162:6233-6237.

24. Xiang J, Rir-Sim-Ah J, Tesfaigzi Y. IL-9 and IL-13 induce mucous cell metaplasia that is reduced by IFN-gamma in a Bax-mediated pathway. Am J Respir Cell Mol Biol. 2008;38 (3):310-317. doi:10.1165/rcmb.2007-0078OC

25. Cerveri I, Brusasco V. Revisited role for mucus hypersecretion in the pathogenesis of COPD. Eur Respir Rev. 2010;19 (116):109-112. doi:10.1183/09059180.00002710

26. Wen FQ, Shen YC. Expectorant therapy revisited in chronic obstructive pulmonary disease. Zhonghua Jie He He Hu Xi Za Zhi. 2011;34(4):243-245.

27. Jartti T, Bønnelykke K, Elenius V, Feleszko W. Role of viruses in asthma. Semin Immunopathol. 2020;42(1):61-74. doi:10.1007/ s00281-020-00781-5

28. Grunstein MM, Hakonarson H, Maskeri N, et al. Autocrine cytokine signaling mediates effects of rhinovirus on airway responsiveness. Am J Physiol. 2000;6:1146-L1153.

29. Baños-Lara Mdel R, Piao B, Guerrero-Plata A. Differential mucin expression by respiratory syncytial virus and human metapneumovirus infection in human epithelial cells. Mediators Inflamm. 2015;2015:347292.

30. Persson BD, Jaffe AB, Fearns R, Danahay H. Respiratory syncytial virus can infect basal cells and alter human airway epithelial differentiation. PLoS One. 2014;9(7):e102368. doi:10.1371/journal.pone. 0102368

31. Stokes KL, Currier MG, Sakamoto K, et al. The respiratory syncytial virus fusion protein and neutrophils mediate the airway mucin response to pathogenic respiratory syncytial virus infection. $J$ Virol. 2013;87(18):10070-10082. doi:10.1128/ JVI.01347-13

32. Farooqi FI, Morgan RC, Dhawan N, Dinh J, Yatzkan G, Michel G. Airway hygiene in COVID-19 pneumonia: treatment responses of 3 critically Ill cruise ship employees. Am J Case Rep. 2020;21:e926596. doi:10.12659/AJCR.926596

33. Sungnak W, Huang N, Bécavin C, et al. SARS-CoV-2 entry factors are highly expressed in nasal epithelial cells together with innate immune genes. Nat Med. 2020;26:681-687. doi:10.1038/s41591-020-0868-6

34. Bustamante-Marin XM, Ostrowski LE. Cilia and mucociliary clearance. Cold Spring Harb Perspect Biol. 2017;9(4):a028241. doi:10.1101/cshperspect.a028241

35. Arumugham $V$ Immunological mechanisms explaining the role of IgE, mast cells, histamine, elevating ferritin, IL-6, D-dimer, VEGF levels in COVID-19 and dengue, potential treatments such as mast cell stabilizers, antihistamines, Vitamin C, hydroxychloroquine, ivermectin and azithromycin. 2020.

36. Prompetchara E, Ketloy C, Palaga T. Immune responses in COVID-19 and potential vaccines: lessons learned from SARS and MERS epidemic. Asian Pac J Allergy Immunol.

37. Cohn L, Homer RJ, Marinov A, Rankin J, Bottomly K. Induction of airway mucus production By T helper 2 (Th2) cells: a critical role for interleukin 4 in cell recruitment but not mucus production. J Exp Med. 1997;186(10):1737-1747. doi:10.1084/ jem.186.10.1737

38. Thai P, Chen Y, Dolganov G, Wu R. Differential regulation of MUC5AC/Muc5ac and hCLCA-1/mGob-5 expression in airway epithelium. Am J Respir Cell Mol Biol. 2005;33(6):523-530. doi:10.1165/rcmb.2004-0220RC 
39. Kreda SM, Davis CW, Rose MC. CFTR, mucins, and mucus obstruction in cystic fibrosis. Cold Spring Harb Perspect Med. 2012;2(9):a009589. doi:10.1101/cshperspect.a009589

40. Saint-Criq V, Gray MA. Role of CFTR in epithelial physiology. Cell Mol Life Sci. 2017;74(1):93-115.

41. Almughem FA, Aldossary AM, Tawfik EA, et al. Cystic fibrosis: overview of the current development trends and innovative therapeutic strategies. Pharmaceutics. 2020;12(7):616.

42. Jarosz-Griffiths HH, Scambler T, Wong CH, et al. Different CFTR modulator combinations downregulate inflammation differently in cystic fibrosis. Elife. 2020;9:e54556. doi:10.7554/ eLife.54556

43. Griffin DO, Jensen A, Khan M, et al. Pulmonary embolism and increased levels of d-dimer in patients with coronavirus disease. Emerg Infect Dis. 2020;26(8):1941-1943. doi:10.3201/ eid2608.201477

44. Huang C, Wang Y, Li X, et al. Clinical features of patients infected with 2019 novel coronavirus in Wuhan, China [published correction appears in Lancet. 2020 Jan 30]. Lancet. 2020;395 (10223):497-506. doi:10.1016/S0140-6736(20)30183-5

45. Liu K, Fang YY, Deng Y, et al. Clinical characteristics of novel coronavirus cases in tertiary hospitals in Hubei Province. Chin Med J (Engl). 2020;133(9):1025-1031. doi:10.1097/ CM9.0000000000000744

46. Wang W, Liu X, Wu S, et al. The definition and risks of cytokine release syndrome in 11 COVID-19-affected critically ill patients with pneumonia: analysis of disease characteristics. J Infect Dis. 2020;jiaa387.

47. Allinson JP, Hardy R, Donaldson GC, et al. The presence of chronic mucus hypersecretion across adult life in relation to chronic obstructive pulmonary disease development. Am J Respir Crit Care Med. 2016;193(6):662-667. doi:10.1164/ rccm.201511-22100C

48. Busse PJ, Zhang TF. Kamal, et al. Chronic exposure to TNF-alpha increases airway mucus gene expression in vivo. J Allergy Clin Immunol. 2005; 116(6):1256-63.

49. Girija ASS, Shankar EM, Larsson M. Could SARS-CoV2-induced hyperinflammation magnify the severity of Coronavirus Disease (CoViD-19) leading to acute respiratory distress syndrome? Front Immunol. 2020;11:1206. doi:10.3389/ fimmu.2020.01206

50. Xia Y, Cai P, Yu F, et al. IL-4-induced caveolin-1-containing lipid rafts aggregation contributes to MUC5AC synthesis in bronchial epithelial cells. Respir Res. 2017;18:174. doi:10.1186/s12931017-0657-z

51. Gharavi NM, Alva JA, Kevin P, et al. Role of the JAK/STAT pathway in the regulation of IL- 8 transcription by oxidized phospholipids in vitro and in atherosclerosis in vivo. J Biol Chem. 2007;282(43):31460-31468. doi:10.1074/jbc. M704267200

52. Yu H, Li Q, Kolosov VP, et al. Interleukin-13 induces mucin 5AC production involving STAT6/SPDEF in human airway epithelial cells. Cell Commun Adhes. 2010;17(4-6):83-92. doi:10.3109/ 15419061.2010 .551682

53. Grunig G, Warnock M, Wakil AE, et al. Requirement for IL-13 independently of IL-4 in experimental asthma. Science. 1998;282:2261-2264. doi:10.1126/science.282.5397.2261

54. Kelly-Welch AE, Hanson EM, Boothby MR, et al. Interleukin-4 and interleukin-13 signalling connection maps. Science. 2003;300:1527-1528. doi:10.1126/science. 1085458

55. Seibold MA. Interleukin-13 stimulation reveals the cellular and functional plasticity of the airway epithelium. Ann Am Thorac Soc. 2018;15(2):S98-S102.

56. Nakanishi K. Unique action of Interleukin-18 on T cells and other immune cells. Front Immunol. 2018. 9:763. doi:10.3389/ fimmu.2018.00763
57. Goswami R, Kaplan MH. A brief history of IL-9. J Immunol. 2011;186(6):3283-3288. doi:10.4049/jimmunol.1003049

58. Demoulin JB, Uyttenhove C, Van Roost E, et al. A single tyrosine of the interleukin-9 (IL-9) receptor is required for STAT activation, antiapoptotic activity, and growth regulation by IL-9. Mol Cell Biol. 1996;16(9):4710-4716.

59. Fung M, Chu Y, Fink J, et al. IL-2- and STAT5-regulated cytokine gene expression in cells expressing the Tax protein of HTLV-1. Oncogene. 2005;24:4624-4633. doi:10.1038/sj. onc. 1208507

60. Wilson MS, Pesce JT, Ramalingam TR, et al. Suppression of murine allergic airway disease by IL-2: anti-IL-2monoclonal antibody-induced regulatory $\mathrm{T}$ cells. $J$ Immunol. 2008;181 (10):6942-6954. doi:10.4049/jimmunol.181.10.6942

61. Bao L, Zhang H, Chan LS. The involvement of the JAK-STAT signaling pathway in chronic inflammatory skin disease atopic dermatitis. JAKSTAT. 2013;2(3):e24137.

62. Li L, Zhao GD, Shi Z, Qi LL, Zhou LY, Fu ZX. The Ras/Raf/ $\mathrm{MEK} / \mathrm{ERK}$ signaling pathway and its role in the occurrence and development of HCC. Oncol Lett. 2016;12(5):3045-3050. doi:10.3892/ol.2016.5110

63. Paunovic V, Harnett MM. Mitogen-activated protein kinases as therapeutic targets for rheumatoid arthritis. Drugs. 2013;73 (2):101-115.

64. Lillehoj EP, Kato K, Lu W, Kim KC. Cellular and molecular biology of airway mucins. Int Rev Cell Mol Biol. 2013;303:139-202.

65. Burgos-Blasco B, Güemes-Villahoz N, Santiago JL, et al. Hypercytokinemia in COVID-19: tear cytokine profile in hospitalized COVID-19 patients. Exp Eye Res. 2020;200:108253.

66. Lee JJ, McGarry MP, Farmer SC, et al. Interleukin-5 expression in the lung epithelium of transgenic mice leads to pulmonary changes pathognomonic of asthma. J Exp Med. 1997;185 (12):2143-2156. doi:10.1084/jem.185.12.2143

67. Tesmer LA, Lundy SK, Sarkar S, Fox DA. Th17 cells in human disease. Immunol Rev. 2008;223:87-113.

68. Hynes GM, Hinks TSC. The role of interleukin-17 in asthma: a protective response? ERJ Open Res. 2020;6(2):00364-2019. doi:10.1183/23120541.00364-2019

69. Coperchini F, Chiovato L, Croce L, Magri F, Rotondi M. The cytokine storm in COVID-19: an overview of the involvement of the chemokine/chemokine-receptor system. Cytokine Growth Factor Rev. 2020;53:25-32. doi:10.1016/j. cytogfr.2020.05.003

70. Zhang D, Facchinetti V, Wang X, Huang Q, Qin J, Su B. Identification of MEKK2/3 serine phosphorylation site targeted by the Toll-like receptor and stress pathways. EMBO J. 2006;25 (1):97-107.

71. Chen Y, Garvin LM, Nickola TJ, Watson AM, Colberg-Poley AM, Rose MC. IL-1 $\beta$ induction of MUC5AC gene expression is mediated by CREB and NF- $\mathrm{BB}$ and repressed by dexamethasone. Am J Physiol Lung Cell Mol Physiol. 2014;306(8):L797-807. doi:10.1152/ajplung.00347.2013

72. Price MM, Oskeritzian CA, Falanga YT, et al. A specific sphingosine kinase 1 inhibitor attenuates airway hyperresponsiveness and inflammation in a mast cell-dependent murine model of allergic asthma. J Allergy Clin Immunol. 2013;131(2):501-11. e1. doi:10.1016/j.jaci.2012.07.014

73. Kankaanranta H, Ilmarinen $\mathrm{P}$, Zhang $\mathrm{X}$, et al. Tumour necrosis factor- $\alpha$ regulates human eosinophil apoptosis via ligation of TNF-receptor 1 and balance between NF-кB and AP-1. PLoS One. 2014;9(2):e90298. doi:10.1371/journal.pone.0090298

74. Wang X, Lin Y. Tumor necrosis factor and cancer, buddies or foes? Acta Pharmacol Sin. 2008;29(11):1275-1288. doi:10.1111/ j.1745-7254.2008.00889.x 
75. Wang IJ, Wu CY, Hu FR. Effect of proinflammatory cytokines on the human MUC5AC promoter activity in vitro and in vivo. Clin Ophthalmol. 2007;1(1):71-77.

76. Thai P, Loukoianov A, Wachi S, Wu R. Regulation of airway mucin gene expression. Annu Rev Physiol. 2008;70:405-429. doi:10.1146/annurev.physiol.70.113006.100441

77. Shishikura Y, Koarai A, Aizawa H, et al. Extracellular ATP is involved in dsRNA-induced MUC5AC production via P2Y2R in human airway epithelium. Respir Res. 2016;17(1):121. doi:10.1186/s12931-016-0438-0

78. Xue L, Barrow A, Fleming VM, et al. Leukotriene E4 activates human Th2 cells for exaggerated proinflammatory cytokine production in response to prostaglandin D2. J Immunol. 2012;188 (2):694-702.

79. Huber M. Activation/Inhibition of mast cells by supra-optimal antigen concentrations. Cell Commun Signal. 2013;11(1):7. doi:10.1186/1478-811X-11-7

80. Rådmark O, Samuelsson B. 5-Lipoxygenase: mechanisms of regulation. J Lipid Res. 2009;50 Suppl(Suppl):S40-5.

81. Hedi H, Norbert G. 5-lipoxygenase pathway, dendritic cells, and adaptive immunity. J Biomed Biotechnol. 2004;2004(2):99-105. doi:10.1155/S1110724304310041

82. Leckie MJ, Ten Brinke A, Khan J, et al. Effects of an interleukin-5 blocking monoclonal antibody on eosinophils, airway hyper-responsiveness, and the late asthmatic response. Lancet. 2000;35(6):2144-2148. doi:10.1016/S0140-6736(00) 03496-6

83. Deeks ED, Brusselle G. Reslizumab in eosinophilic asthma: a review. Drugs. 2017;77:777-784.

84. Brightling CE, Bleecker ER, Panettieri RA Jr, et al. Benralizumab for chronic obstructive pulmonary disease and sputum eosinophilia: a randomised, double-blind, placebo-controlled, phase 2 study. Lancet Respir Med. 2014;2:891-901. doi:10.1016/S22132600(14)70187-0

85. Arora S, Ahmad S, Irshad R, et al. TLRs in pulmonary diseases. Life Sci. 2019;15(233):116671. doi:10.1016/j.1fs.2019.116671

86. Wang L, Quan Y, Yue Y, Heng X, Che F. Interleukin-37: a crucial cytokine with multiple roles in disease and potentially clinical therapy. Oncol Lett. 2018;15(4):4711-4719.

87. Zhang L, Zhang J, Gao P. The potential of interleukin-37 as an effective therapeutic agent in asthma. Respir Res. 2017;18(1):192. doi:10.1186/s12931-017-0675-x

88. Nold MF, Nold-Petry CA. Zepp, et al. IL-37 is a fundamental inhibitor of innate immunity. Nat Immunol. 2010;11:1014-1022. doi:10.1038/ni.1944

89. Nold-Petry CA, Lo CY, Rudloff I, et al. IL-37 requires the receptors IL-18Ralpha and IL-1R8 (SIGIRR) to carry out its multifaceted anti-inflammatory program upon innate signal transduction. Nat Immunol. 2015;16:354-365. doi:10.1038/ ni.3103

90. Abdalla AE, Li Q, Xie L, Xie J. Biology of IL-27 and its role in the host immunity against Mycobacterium tuberculosis. Int J Biol Sci. 2015;11(2):168-175. doi:10.7150/ijbs.10464

91. Bosmann M, Ward PA. Modulation of inflammation by interleukin-27. J Leukoc Biol. 2013;94(6):1159-1165. doi:10.1189/jlb.0213107

92. de Almeida Nagata DE, Demoor T, Ptaschinski C, et al. IL27R-mediated regulation of IL-17 controls the development of respiratory syncytial virus-associated pathogenesis. Am $J \quad$ Pathol. 2014;184(6):1807-1818. doi:10.1016/j. ajpath.2014.02.004

93. Ito $\mathrm{T}$, Tanaka $\mathrm{T}$, Nakamaru $\mathrm{K}$, et al. Interleukin-35 promotes the differentiation of regulatory $\mathrm{T}$ cells and suppresses $\mathrm{Th} 2$ response in IgG4-related type 1 autoimmune pancreatitis. J Gastroenterol. 2020;55(8):789-799. doi:10.1007/s00535-020-01689-5
94. Huang A, Cheng L, He M, Nie J, Wang J, Jiang K. Interleukin-35 on B cell and $\mathrm{T}$ cell induction and regulation. J Inflamm (Lond). 2017;14(16). doi:10.1186/s12950-017-0164-5

95. Heinrich PC, Behrmann I, Müller-Newen G, Schaper F, Graeve L. Interleukin-6-type cytokine signalling through the gp130/Jak/ STAT pathway. Biochem J. 1998;334(Pt 2):297-314. doi:10.1042/bj3340297

96. Seelaender M, Neto JC, Pimentel GD, Goldszmid RS, Lira FS. Inflammation in the disease: mechanism and therapies 2014. Mediators Inflamm. 2015;2015:169852. doi:10.1155/2015/169852

97. Van de Veerdonk FL, Stoeckman AK, Wu G, et al. IL-38 binds to the IL-36 receptor and has biological effects on immune cells similar to IL-36 receptor antagonist. Proc Natl Acad Sci U S A. 2012;109(8):3001-3005. doi:10.1073/pnas.1121534109

98. Pavord ID, Chanez P, Criner GJ, et al. Mepolizumab for Eosinophilic Chronic Obstructive Pulmonary Disease. N Engl J Med. 2017;377:1613-1629.

99. Queen D, Ediriweera C, Liu L. Function and regulation of IL-36 signaling in inflammatory diseases and cancer development. Front Cell Dev Biol. 2019;7:317. doi:10.3389/fcell.2019.00317

100. Boutet MA, Nerviani A, Pitzalis C. IL-36, IL-37, and IL-38 cytokines in skin and joint inflammation: a comprehensive review of their therapeutic potential. Int J Mol Sci. 2019;20(6):1257. doi:10.3390/ijms20061257

101. Madonna S, Girolomoni G, Dinarello CA, Albanesi C. The significance of IL-36 hyperactivation and IL-36R targeting in psoriasis. Int J Mol Sci. 2019;20(13):3318. doi:10.3390/ijms20133318

102. Bassoy EY, Towne JE, Gabay C. Regulation and function of interleukin-36 cytokines. Immunol Rev. 2018;281(1):169-178. doi:10.1111/imr.12610

103. Atal S, Fatima Z. IL-6 inhibitors in the treatment of serious COVID-19: a promising therapy? Pharmaceut Med. 2020;34 (4):223-231

104. Goldbach-Mansky R. Blocking interleukin-1 in rheumatic diseases. Ann N Y Acad Sci. 2009;1182(1):111-123. doi:10.1111/ j.1749-6632.2009.05159.x

105. Sciascia S, Aprà F, Baffa A, et al. Pilot prospective open, single-arm multicentre study on off-label use of tocilizumab in patients with severe COVID-19. Clin Exp Rheumatol. 2020;38(3):529-532.

106. Russell B, Moss C, George G, et al. Associations between immune-suppressive and stimulating drugs and novel COVID-19-a systematic review of current evidence. Ecancermedicalscience. 2020;14:1022. doi:10.3332/ecancer.2020.1022

107. Kim JH, Gupta SC, Park B, Yadav VR, Aggarwal BB. Turmeric (Curcuma longa) inhibits inflammatory nuclear factor (NF)- $\kappa \mathrm{B}$ and NF- $\mathrm{NB}$-regulated gene products and induces death receptors leading to suppressed proliferation, induced chemosensitization, and suppressed osteoclastogenesis. Mol Nutr Food Res. 2012;56 (3):454-465. doi:10.1002/mnfr.201100270

108. Ghandadi M, Sahebkar A. Curcumin: an effective inhibitor of interleukin-6. Curr Pharm Des. 2017;23(6):921-931. doi:10.2174/1381612822666161006151605

109. Mao QQ, Xu XY, Cao SY, et al. Bioactive compounds and bioactivities of ginger (Zingiber officinale Roscoe). Foods. 2019;8(6):185. doi:10.3390/foods 8060185

110. Ohishi T, Goto S, Monira P, Isemura M, Nakamura Y. Antiinflammatory action of green tea. Antiinflamm Antiallergy Agents Med Chem. 2016;15(2):74-90. doi:10.2174/ 1871523015666160915154443

111. Cabrita I, Benedetto R, Schreiber R, Kunzelmann K. Niclosamide repurposed for the treatment of inflammatory airway disease. JCI Insight. 2019;4(15):e128414. doi:10.1172/jci.insight.128414

112. Tufts Medical Center. Niclosamide for mild to moderate COVID-19. NLM identifier: NCT04399356. Available from: https://clinical trials.gov/ct2/show/NCT04399356. Accessed September 1, 2020. 
113. Miklossy G, Hilliard TS, Turkson J. Therapeutic modulators of STAT signalling for human diseases. Nat Rev Drug Discov. 2013;12(8):611-629. doi:10.1038/nrd4088

114. Yale University. Tofacitinib for Treatment of Moderate COVID-19 (I-TOMIC). NLM identifier: NCT04415151. Available from: https://clinicaltrials.gov/ct2/show/ NCT04415151. Accessed July 29, 2020..

115. Gerriets V, Bansal P, Goyal A, et al. Tumor Necrosis Factor (TNF) Inhibitors. [Updated 2020 Jul 4]. In: StatPearls [Internet]. Treasure Island (FL): StatPearls Publishing; 2020 Jan. Available from: https://www.ncbi.nlm.nih.gov/books/ NBK482425/. Accessed December 11, 2020.

116. Tufts Medical Center. A Phase 2 trial of infliximab in coronavirus disease 2019 (COVID-19). NLM identifier: NCT04425538. Available from: https:/clinicaltrials.gov/ct2/show/ NCT04425538. Accessed June 1, 2020.

117. Choy EH, De Benedetti F, Takeuchi T, Hashizume M, John MR, Kishimoto T. Translating IL-6 biology into effective treatments. Nat Rev Rheumatol. 2020;16(6):335-345. doi:10.1038/s41584020-0419-z

118. Genentech, Inc. A study to evaluate the efficacy and safety of tocilizumab in hospitalized participants with COVID-19 pneumonia. NLM identifier: NCT04372186. Available from: https://clinicaltrials.gov/ct2/show/NCT04372186. Accessed May 14, 2020.
119. Wu KK, Dao H Jr. Off-label dermatologic uses of IL-17 inhibitors [published online ahead of print, 2020 Mar 9]. J Dermatolog Treat. 2020;1-7. doi:10.1080/09546634.2020.1737638

120. Lomonosov Moscow State University Medical Research and Educational Center. COLchicine versus ruxolitinib and secukinumab in open prospective randomized trial (COLORIT). NLM identifier: NCT04403243. Available from: https://clinicaltrials. gov/ct2/show/NCT04403243. Accessed May 8, 2020

121. Fenini G, Contassot E, French LE. Potential of IL-1, IL-18 and inflammasome inhibition for the treatment of inflammatory skin diseases. Front Pharmacol. 2017;8:278. doi:10.3389/fphar. 2017.00278

122. University Hospital, Basel, Switzerland. Canakinumab in patients with COVID-19 and Type 2 diabetes (CanCovDia). NLM identifier: NCT04510493. Available from: https://clinicaltrials.gov/ct2/ show/NCT04510493. Accessed September 2020.
Journal of Inflammation Research

\section{Publish your work in this journal}

The Journal of Inflammation Research is an international, peerreviewed open-access journal that welcomes laboratory and clinical findings on the molecular basis, cell biology and pharmacology of inflammation including original research, reviews, symposium reports, hypothesis formation and commentaries on: acute/chronic inflammation; mediators of inflammation; cellular processes; molecular

\section{Dovepress}

mechanisms; pharmacology and novel anti-inflammatory drugs; clinical conditions involving inflammation. The manuscript management system is completely online and includes a very quick and fair peerreview system. Visit http://www.dovepress.com/testimonials.php to read real quotes from published authors. 